\title{
Epidemiological tools for effective surveillance of porcine cysticercosis in Africa
}

\author{
J. S. E. Goussanou ${ }^{1,2}$, M. T. Kpodekon ${ }^{1,2}$, A. K. I. Youssao ${ }^{1}$, S. Farougou ${ }^{1}$ and N. Korsak ${ }^{3}$
}

1. Department of animal Production and Heath, Ecole Polytechnique of Abomey-Calavi, University of Abomey-Calavi, Benin; 2. Laboratory of Applied Biology, University of Abomey-Calavi, Benin; 3. Food Science Department, Faculty of Veterinary Medicine, University of Liège, Liège, Belgium.

Corresponding author: J. S. E. Goussanou, Tel: 0022995790449/0022997168992, e-mail: judgouss@yahoo.fr Received: 22-12-2013, Revised: 01-02-2014, Accepted: 07-02-2014, Published online: 06-03-2014

doi: 10.14202 /vetworld.2014.125-134

How to cite this article: Goussanou J SE, Kpodekon MT, Youssao AKI, Farougou S and Korsak N (2014) Epidemiological tools for effective surveillance of porcine cysticercosis in Africa, Veterinary World 7(3): 125-134.

\begin{abstract}
Porcine cysticercosis is widely distributed in developing countries. Many tools were developed for effective control of the tapeworm in endemic countries. Tongue examination, meat inspection and Ag-ELISA were widely used in epidemiological survey. Both tongue examination and meat inspection are highly specific but less sensitive. To improve performance of AgELISA, unambiguous test based on nanobodies was performed. Immunodiagnostic tests based on PCR, flows through assay (FTA), Surface Enhanced Laser Desorption-Ionization Time of Flight (SELDI-TOF) were also developed. Less data were reported using spatial statistical analysis hence multiples approaches were available for effective epidemiological survey of porcine cysticercosis.
\end{abstract}

Keywords: Ag-ELISA, cysticercosis, epidemiology, GIS, meat inspection.

\section{I ntroduction}

Taenia solium is a tapeworm responsible of serious public health problem in developing countries $[1,2]$. This tapeworm is transmitted to human by absorption of $T$. solium eggs or when eating undercooked pork. In humans, the larval stage of $T$. solium is responsible for conditions named cysticercosis or neurocysticercosis. Tongue examination and meat inspection are the main methods used for identifying infected pigs. The specificity of the tests is assessed to be close to $100 \%$; however the sensitivity is variable, depending very much on the degree of infection in the pig [3]. Different techniques have been described to detect antibodies and antigens of T. solium infections in man and pigs: enzyme linked immunosorbent assay (ELISA), dipstick-ELISA, latex agglutination, immunoblot techniques, antigen detection based on sandwich enzyme-linked immunosorbent assay (Ag-ELISA) [39]. Antigens detection based on Ag-ELISA was therefore effectively used to detect porcine and human cysticercosis. However, Ag-ELISA is not highly specific and sensitive. Hence, other immunodiagnostics tests and spatial statistical analyses of porcine cysticercosis were developed in order to be used in epidemiological survey.

This paper aimed to review epidemiological tools developed for the control of porcine cysticercosis.

\section{Macroscopic tools for porcine cysticercosis diagnostic}

Porcine cysticercosis is widely distributed among

Copyright: The authors. This article is an open access article licensed under the terms of the Creative Commons Attribution License (http://creativecommons.org/licenses/by/2.0) which permits unrestricted use, distribution and reproduction in any medium, provided the work is properly cited. different areas in developing countries. In Africa, the tapeworm was identified in Western Africa, Eastern Africa and Southern Africa. Meat inspection and lingual examination are frequently used for the diagnostic of the porcine cysticercosis in Africa.

Lingual examination: Lingual examination was widely used in all the diagnostic studies dealing with the assessment of $T$. solium cysticercosis infection in Africa [10]. To perform the test, the pig is firmly restrained in lateral recumbency and a hard wooden stick is used to open the mouth and keep it open. Using mutton cloth as an aid, the tongue is pulled out, examined and palpated along its entire ventral aspect to check for presence or absence of cysticerci. A pig found to have one or more cyst(s) on the tongue is considered positive for $T$. solium cysticercosis. If carried out correctly, the specificity of tongue palpation is close to $100 \%[3,10]$. The sensitivity of the technique, is however variable, depending very much on the degree of infection in the pig. A Bayesian approach was used to estimate the performance of tongue inspection [3]. The performance indicators of this test were: 0.21 for sensitivity (se) and 1.00 for specificity (sp). None of the light infections and only about half of the heavy and moderate infections have been detected by tongue inspection. Nevertheless, despite of the low sensitivity of the lingual examination, this diagnostic test is useful in assessing of the spatial distribution of the tapeworm [11].

Meat inspection: Post-mortem inspection for diagnostic of $T$. solium cysticercosis was described [12,13]. Meat inspection includes long and parallel incisions into the external masseter muscles on both sides of the face in an upward direction to severe completely the parotid 
gland below the ear. The abdominal and diaphragmatic muscles, the root of the tongue and the tongue of all pigs should be incised and the blade of the tongue viewed and palpated. The heart of all pigs will be viewed, palpated and opened up. A deep incision will be made into the septum. Incisions will also be made in the triceps brachii muscle proximal to the elbow joint. Heavy infestation with Cysticercus cellulosae calls for carcass condemnation. In light or moderate infestation, the carcass may be conditionally approved pending heat or freezing treatment. Cysts that were encountered on incisional and intact surfaces were classified as either viable (translucent, fluid-filled with invaginated whitish protoscolices visible) or degenerated (black, sand-like or powdery contents) [14]. The specificity of meat inspection is estimated to be close to $100 \%$ [3, 15]. But it is admitted that, meat inspection is less sensitive [3]. This test is unable to exclude T. solium infected pork from the food chain since it failed to detect infections in $61.3 \%$ of infected animals [15]. Thus, the method is imperfect for use in epidemiological surveys and cannot be applied to monitor control programs of T. solium. Light infections go undetected in carcass inspection. Therefore, to control the parasite effectively in endemic areas, more sensitive and specific diagnostic methods have been used, such as immunodiagnostic tools [3].

\section{ELI SA for the detection of circulating T. solium antigens (Ag-ELI SA)}

Ag-ELISA (Antigens detection based on sandwich enzyme-linked immunosorbent assay) test for the detection of circulating T. solium antigens consists of collection of about $5 \mathrm{ml}$ of blood from the jugular vein of large pigs or anterior vena cava of small pigs into plain tubes with clot activator. After centrifugation, the serum from each tube is transferred into two labelled cryovial tube aliquots for each pig and stored at $-20{ }^{\circ} \mathrm{C}$ until tested. The samples are first treated with trichloroacetic acid (TCA) to break the antigen-antibody complexes and then tested at a final dilution of 1:4. Briefly the sandwich assay consisted of coating the plates with capturing monoclonal antibody (B158C11 A10), blocking, addition of TCA treated sera, after which the second biotin labeled antibody (B60H8A4), streptavidin labeled peroxidase and ortho phenylenediamine (OPD) substrate are added consecutively. Washings are carried out between the steps. The reaction is stopped using sulphuric acid and the plates are read in a spectrophotometer at a wavelength of 492 $\mathrm{nm}$. The cutoff is calculated using a modified Student ttest programmed in MS Excel sheet, by comparing the optical density of each serum sample with a series of negative serum samples obtained from a pig without any history of cysticercosis in each study area at a probability level of $\mathrm{P}<0.001$. A serum sample is considered positive when the ratio (optical density of test sample/optical density cut-off) is $\geq 1.0$. The specificity and sensitivity of Ag-ELISA test were found to be $86.7 \%$ and $94.7 \%$, respectively [3]. For several authors, Ag-ELISA test is useful for identification of active infection $[16,17]$. In contrast, cross reactions were detected with Taenia hydatigena $[3,18]$.

To improve the performance of Ag-ELISA in the detection of porcine cysticercosis, nanobodies derived from camels was used to develop unambiguous specific tests [19]. Nanobodies owned remarkable characteristics such as being small, nonimmunogenic, very stable, highly soluble, and easy to produce in large quantities. Nanobodies technologies were developed and used in order to control disease such as cancer. [20]. Nanobodies are antibody-derived single domain proteins that contain the unique structural and functional properties of only heavy chain antibodies that naturally occur in camels [20]. Nanobodies are encoded by single genes and are efficiently produced in eukaryotic and prokaryotic hosts including bacteria and yeast [21]. Because of their unique three-dimensional structure, nanobodies have access to cavities or clefts on the surface of proteins [22, 23]. Nanobodies are ideal tools to selectively stabilize specific conformational states of membrane proteins [24,25]. Hence, nanobodies were cloned after immunization of dromedaries with $T$. solium cysticercosis and phage procedure [19]. The nanobodies that were obtained did not cross react with Taenia hydatigena, Taenia saginata, Taenia crassiceps or Trichinella spiralis and were categorized into four epitopebinding groups. The glycoprotein $14 \mathrm{kDa}$ (Ts14), that was found, reacted with antigen but the nanobodies also reacted with other proteins of the same family. When tested with a sandwich ELISA on cyst fluid, one particular nanobody detected its cognate serum antigens in a species-specific inhibition ELISA.

On the other hand and in perspective to improve Ag-ELISA response, the vesicular cyst antigen with 2Dimensional IgG immunoblot was used to test the reactivity of cysticercotic sera of pigs [26]. The author reported diversity among the proteins and antigens of vesicular cyst and a diverse IgG antibodies response. Furthermore, using the random amplified polymorphic DNA markers (RAPDs) to assess the genetic variability among cysticerci infected pigs, authors found genetically difference in cysticerci infected pigs [27]. Therefore, a possible significant source of diversity in Taenia solium infectiveness and pathogenicity was suggested [26].

\section{Surface enhanced laser desorption-ionization time of flight ( SELDI -TOF)}

The SELDI-TOF was used to identify biomarkers of Taenia solium cysticercosis for viable cyst (active disease) and degenerated cyst (inactive disease) [28]. SELDI-TOF is a proteomic high-throughput technique, which has been improved with the progression of protein-chip systems. Three major components constitute the instrumentation of SELDI-TOF MS technology: protein chip arrays, a mass analyzer, and data analysis software. The protein chip arrays are the 
heart of the SELDI-TOF MS technology. Using chromatographic surfaces to retain proteins and peptides on ProteinChip arrays based on their physicochemical properties, the platform performs direct analysis via Time-Of-Flight-Mass Spectrography (TOF-MS). Peak patterns are formed via MS, which represent protein expression profiles. The location and intensity of every peak in the pattern reflect the mass over charge ratio $(\mathrm{m} / \mathrm{z})$ and abundance of the corresponding protein $[29,30]$. This high-throughput technique allows the screening of low molecular weight proteins compared with other traditional methods, such as 2D gel electrophoresis. Combined with bioinformatic approaches, SELDI-TOF is valuable in establishing protein expression profiles and in discovering new biomarkers with high sensitivity and specificity [29,31-33]. SELDI-TOF-based techniques with bioinformatics have also been successfully applied for early detection of several cancer types [34,35], liver fibrosis, cirrhosis in patients with chronic hepatitis B virus (HBV) [36,38 ] and chronic hepatitis $\mathrm{C}$ virus (HCV) infection $[39,40]$. Nevertheless, a major concern in study design was reported [41-43] and twenty sources of variation affecting SELDI-TOF process was found [44]. SELDITOF MS is a high throughput technique that allows hundreds of samples to be screened for disease biomarker identification in a relatively short time [45]. Otherwise, the system is manual, time consuming, and prone to human error. The cost of protein chip arrays seems to be high at \$75/chip (8 spots). Using SELDITOF, 13 specific biomarkers were found for the viable phenotype, 9 specific for the degenerated phenotype and 8 specific for either viable or degenerated cysts [28]. Among biomarkers discovered in the experimental sample, five biomarkers (clusterin, lecithin-cholesterol acyltransferase, vitronectin, and apolipoprotein A-I) were identified to increase serum expression in pigs infected with viable cyst. Haptoglobin was identified as biomarker that increase serum expression in animal infected with degenerated cysts. However, when tested biomarkers with field samples, only three biomarkers were to specific to increase serum expression.

\section{Development of immunodiagnostic test with polymerase chain reaction (PCR)}

A PCR protocol targeting mitochondrial cytochrome oxidase (COI) gene in sera samples was used for the diagnosis of porcine cysticercosis [46]. According to these authors, the use of PCR in serum for the diagnosis of porcine cysticercosis has a high specificity and the assay did not showed cross-reactivity with toxoplasmosis and trichinellosis. However, this technique is also specific when used to test the other pig taeniids, mainly Taenia hydatigena, Taenia asiatica [47]. The same authors showed that bioinformatic analysis by means of NCBI/BLAST and ClustalW programmes has shown high homologies in mitochondrial cytochrome oxidase gene among the different Taenia species. Since, the diagnosis of porcine cysticercosis based on PCR protocol targeting mitochondrial cytochrome oxidase (COI) gene as reported [46] is useful to prove existence of the larval stages belonging to the Taenia genus [47]. In contrast, PCR was used for the diagnostic of porcine cysticercosis after inspection of the carcass [48]. Nevertheless to perform this PCR protocol, genomic DNA was extracted from $T$. solium cysticerci dissected from naturally infected cysticercosis positive pigs. The oligonucleotide primers used were TBR-3 (5'-GGC TTG TTT GAATGG TTT GAC G-3' from AB020395; positions 34-55) and TBR-6 (5'-GCT ACT ACA CCT AAA TTC TAA CC-3'; positions 319-297) and the primers Cox1 I (5'-TTG TTATAA ATT TTT GAT TAC TAA C-3' from AB066490 to AB066492; positions 165-189) and Cox1 II (5'-GAC ATA ACA TAA TGA AAA TG-3'; positions 11481129). The TBR primers and the Cox 1 primers yielded products of 286 and $984 \mathrm{bp}$, respectively, in cysticercosis positive cases with the PCR test. Both sets of primers were found to be highly specific, since they did not yield any PCR product in negative controls.

\section{Development of immunodiagnostic test with flow through assay (FTA) method}

Flow-through assay (FTA) is a membrane based immunoassay. This assay is based on a principle of direct competitive ELISA [49,50]. Antibody of the tested molecule is coated on a membrane surface followed by an addition of tested molecule enzyme conjugate. The molecule and its conjugate compete for the limited antibody binding sites. After dried step in an incubator and a washing step, the enzyme substrate is added and reacts with the tested molecule-coupled enzyme and color develops. A FTA for the serodiagnostic of porcine cysticercosis using cyst fluid antigen (CFA) and the whole cyst fluid antigen (WCA) has been developed [51]. The test consisted of coating the $T$. solium metacestode antigen on cellulose acetate membranes in order to increase its capturing by the antibodies in the serum sample. The bound antibodies are visualized by the addition of protein A colloidal gold conjugate, which served as antigen-antibody detecting reagent imparting pink color to the membrane as a dot. Performing the techinique, cyst fluid antigen was prepared using Chung [52] method with modification. The proteins within the two antigens were estimated by using method of Lowry with bovine plasma globulins as a standard [53]. The performance observed for FTA were better with CFA (96.0\% sensitivity; $96.0 \%$ specificity) compared to WCA (92.0\% sensitivity; $96.0 \%$ specificity) [51]. When comparing result with the enzyme-linked immunosorbent assay, the sensitivity for both the antigens were $96 \%$ while the specificities with CFA and WCA were 96 and $92 \%$, respectively. The authors found that the cross-reaction was observed in one out of eight hydatidosis positive pigs (12.5\%) with CFA by both the assays. The highest diagnostic accuracy $(96 \%)$ was obtained with CFA-FTA and CFA-ELISA. Those latest 
antigens: CFA, Cyst wall antigen (CWA) and crude lysate antigen (CLA) were used to identify immune response in sera collected from neurocysticercosis patients [54]. The authors found the highest positive cellular response with CFA. This cellular response was followed by crude lyase antigen and finally by crude wall antigen. When fractioned the CFA, the fractions $\mathrm{F} 1(10.51 \pm 4.83)$ and F4 (9.91 \pm 3.91$)$ revealed maximum response. Nevertheless, the significantly level of cytokine was revealed with the fraction F1 that induced TNF- $\alpha$ $(115.18 \pm 91.2)$ secretion, and F2 that induced IL-4 $(15.69 \pm 5.79)$ and IL-10 (117.81 \pm 41.89$)$ secretion. On the other hand, Excretory secretory antigen showed the highest sensitivity and Crude soluble extract antigen showed the highest specificity when comparing the performance of Crude soluble extract antigen, Excretory secretory antigen and Lower molecular mass antigen fraction $(10-30 \mathrm{kDa})$ on the diagnostic performances of neurocysticercosis [55]. In contrast comparing vesicular fluid (VF) and a glycoprotein fraction (LLaGp fraction), purified from a whole parasite extracted by lentil lectin affinity chromatography, the vesicular fluid ELISA showed $100 \%$ sensitivity and specificity whereas the sensitivity and specificity was found lower with the LLa-Gp ELISA [56]. Despite the variation on the sensitivity and specificity registered using CFA and the WCA in Flow-through assay, this method of diagnostic is rapid, easy-to-use [57]. The method does not require any equipment and more importantly, any individual can perform this assay. However, since the method is semi-quantitative, interpretation of results may be difficult when the tested molecule concentration of the test sample is close to the method cut-off level.

\section{Spatial analysis tools for porcine cysticercosis survey}

Disease analysis at geographical level would be beneficial for a better understanding of cause of diseases and actions to be promoted in the field of epidemiological control. One of the techniques used to reveal spatial distribution of diseases is clusters detection. In epidemiology, a cluster is a number of health events located close together in space and/or time [58]. Identifying spatial and spatio-temporal clusters of cases could help: (i) to generate new information for further etiologic studies; (ii) to identify risk areas where to focus the surveillance and allocate the resources (antibiotics, rapid diagnostic tests...); (iii) to develop cost-efficient vaccination strategies [59]. Spatial analysis of diseases can be performed using approaches based on Bayesian geo-statistical, K-functions, Generalized Additive Models (GAM), Cuzick-Edwards test, Besag -Newell test $[60,61]$ or SaTScan (Kulldorff M. and Information Management Services, http://www. satscan.org/). These aforementioned statistical spatial analysis approaches were used to detect clusters of the following conditions: meningococcal meningitis, Campylobacter spp. in humans and in broiler flocks, schistosomiasis, Rhodesian Human African Trypanosomiasis, Helminth Co-Infection and Co-Intensity, Hookworm, Dengue Virus, tuberculosis [62-69]. Both global and local clusters were assessed by using varying statistical spatial methods. To perform a global cluster in a study areas, the most frequently used tests are K-function, Diggle and Chetwynd's bivariate Kfunction [70-73] and the Potthoff-Whittinghill method (PW) [74-78]. Moran's I statistic, Cuzick and Edwards's nearest neighbors and Tango's maximized excess events tests (MEET) are less used [79-81]. Tango's MEET generally has the best statistical power, adjusts for multiple testing and has the added value of being able to evaluate spatial autocorrelation and spatial heterogeneity [82]. Local clusters of diseases are performed by using Anselin's local indicator of spatial association (LISA) and the Besag-Newell test [61,83-85]. Nevertheless, Kulldorff's spatial scan statistic is most frequently used for detection of local cluster because the test can adjust for multiple testing and heterogeneous background population densities, along with otherconfounding variables. Kulldorff's spatial scan statistic is also applicable to both point and aggregated data, and has been adapted to detect noncircular clusters $[86,87,88]$. Diggle's test and Stone's conditional test is used to evaluate focal clustering $[89,90]$ and to determine whether risk declines from pre-specified point sources $[76,85]$. When performed power evaluation of diseases clustering tests, spatial scan statistic has good power in detecting local clusters [82]. Tango's MEET is useful for detection of urban clusters and Besag-Newell's test for detecting mixed clusters with a right choice of parameter. The Cuzick-Edwards' k-NN test was found to have a good power in detecting hot spot cluster but the power of the test depends upon the right choice of the parameter. With regard to the detection of global clusters, Tango's MEET has the highest power. Nevertheless, the spatial scan statistic performs diseases clusters well, but not as well as Tango's MEET [82]. However, Cuzick-Edwards' k-NN test is useful to perform clusters with very small distance if a right choice of parameter has been done. Statistical spatial analysis approaches were seldom used to control porcine cysticercosis [11,91]. By using $\mathrm{K}$ functions to assess general cluster of porcine cysticercosis and SatScan to detect local cluster, authors found that the two approaches match well [11]. In the district of Matapalo (Peru), distance to nearest neighbor was used to detect hotspots surrounding taenia solium tapeworm carriers [92]. The risk-adjusted nearest neighbour hierarchical spatial clustering (Rnnh) was used to detect clusters of porcine cysticercosis in a Rural Area of Eastern Zambia-A Community [93]. SaTScan was used to determine clusters of different indices of Taenia solium infection in Vellore district of Tamil Nadu State in India [94]. In western Kenya, the k-1 nearest neighbours local convex hull method was used to determine the spatial ecology of free-ranging domestic pigs [95]. 
Table-1. Characteristics of porcine cysticercosis detection tests

\begin{tabular}{|c|c|c|c|c|c|c|c|}
\hline Type of tests & $\begin{array}{l}\text { Method of detection of } \\
\text { porcine cysticercosis }\end{array}$ & $\begin{array}{l}\text { Materials used } \\
\text { for detection }\end{array}$ & Sensitivity & Specificity & type of output & Fields of application & References \\
\hline \multirow{3}{*}{$\begin{array}{l}\text { Tongue } \\
\text { examination } \\
\text { Meat } \\
\text { inspection } \\
\text { Ag-ELISA }\end{array}$} & Visual exam & - & $0.161-0.708$ & 1.000 & Qualitative & $\begin{array}{l}\text { Ante mortem inspection } \\
\text { Epidemiological survey }\end{array}$ & {$[3,10,11]$} \\
\hline & Incision and visual exam & knife & $0.221-0.387$ & 1.000 & Qualitative & $\begin{array}{l}\text { Post mortem inspection } \\
\text { Epidemiological survey }\end{array}$ & {$[3,112]$} \\
\hline & Serology base on antigen & $\begin{array}{l}\text { ELISA reader } \\
\text { Protein chip arrays }\end{array}$ & $0.645-0.867$ & $0.841-0.947$ & Quantitative & Epidemiological survey & {$[3,105]$} \\
\hline SELDI-TOF & Proteomic high-throughput & $\begin{array}{l}\text { Mass analyzer, } \\
\text { Data analysis } \\
\text { software }\end{array}$ & - & - & Quantitative & Test not performed & [28] \\
\hline \multirow[t]{2}{*}{$\begin{array}{l}\text { PCR } \\
\text { FTA }\end{array}$} & $\begin{array}{l}\text { Genomic DNA technique } \\
\text { Direct competitive ELISA }\end{array}$ & $\begin{array}{l}\text { PCR equipment } \\
\text { Flow through }\end{array}$ & - & - & Quantitative & Test not performed & {$[46]$} \\
\hline & & module & - & - & Semi-quantitati & Test not performed & [51] \\
\hline
\end{tabular}

Table-2. Characteristics of statistical tools use for diseases clusters detection

\begin{tabular}{|c|c|c|c|c|c|c|c|}
\hline Type of tests & $\begin{array}{l}\text { Type of } \\
\text { clusters }\end{array}$ & Method of detection of clusters & $\begin{array}{l}\text { Software that } \\
\text { implement the } \\
\text { function }\end{array}$ & $\begin{array}{l}\text { Categories } \\
\text { of input data }\end{array}$ & Input data & $\begin{array}{l}\text { Fields of } \\
\text { application }\end{array}$ & References \\
\hline \multirow[t]{9}{*}{$\begin{array}{l}\text { Spatial } \\
\text { analysis } \\
\text { tools }\end{array}$} & Global & K-function, & $\begin{array}{l}\text { CrimeStat, R, } \\
\text { ArcGIS, MATLAB, } \\
\text { ClusterSeer }\end{array}$ & $\begin{array}{l}\text { Case event } \\
\text { Case-control }\end{array}$ & $P \& D$ & $\begin{array}{l}\text { Epidemiological } \\
\text { survey }\end{array}$ & \multirow[t]{9}{*}{$\begin{array}{l}{[113,114,} \\
115,116, \\
117]\end{array}$} \\
\hline & Global & $\begin{array}{l}\text { Diggle and Chetwynd's bivariate } \\
\text { K-function, }\end{array}$ & CrimeStat, & Case-control & $P \& D$ & $\begin{array}{l}\text { Epidemiological } \\
\text { survey }\end{array}$ & \\
\hline & Global & Potthoff-Whittinghill method (PW). & R (Dcluster package) & Case event & $P \& D$ & $\begin{array}{l}\text { Epidemiological } \\
\text { survey }\end{array}$ & \\
\hline & Global & Moran's I statistic* & $\begin{array}{l}\text { CrimeStat, R, } \\
\text { ClusterSeer, } \\
\text { GeoDa }\end{array}$ & Continuous & $\mathrm{P}, \mathrm{Ag}, \mathrm{D} \& \mathrm{C}$ & $\begin{array}{l}\text { Epidemiological } \\
\text { survey }\end{array}$ & \\
\hline & Global & $\begin{array}{l}\text { Cuzick and Edwards's nearest } \\
\text { neighbors }{ }^{*}\end{array}$ & $\begin{array}{l}\text { Space Time } \\
\text { Intelligence } \\
\text { System (STIS), } \\
\text { ClusterSeer, R }\end{array}$ & $\begin{array}{l}\text { Case event } \\
\text { Case-control }\end{array}$ & $\begin{array}{l}\text { P\&D } \\
\text { Adaptive for } \\
\text { Continuous }\end{array}$ & $\begin{array}{l}\text { Epidemiological } \\
\text { survey }\end{array}$ & \\
\hline & Global & $\begin{array}{l}\text { Tango's maximized excess events } \\
\text { tests }(\mathrm{MEET})^{\star}\end{array}$ & $\mathrm{R}$ & Case-control & $P, A g \& D$ & $\begin{array}{l}\text { Epidemiological } \\
\text { survey }\end{array}$ & \\
\hline & Local & $\begin{array}{l}\text { Anselin's local indicator of spatial } \\
\text { association (LISA) }\end{array}$ & $\begin{array}{l}\text { CrimeStat, R, } \\
\text { GeoDa, ArcGIS, } \\
\text { SpaceStat }\end{array}$ & Continuous & $P \& C$ & $\begin{array}{l}\text { Epidemiological } \\
\text { survey }\end{array}$ & \\
\hline & Local & Besag-Newell test & $\begin{array}{l}\mathrm{R} \text { (Dcluster package) } \\
\text { ClusterSeer. }\end{array}$ & $\begin{array}{l}\text { Case event } \\
\text { Case-control }\end{array}$ & $\mathrm{P}, \mathrm{Ag} \& \mathrm{D}$ & $\begin{array}{l}\text { Epidemiological } \\
\text { survey }\end{array}$ & \\
\hline & Local & Kulldorff's spatial scan statistic & $\begin{array}{l}\text { SaTScan } \\
\text { R, ClusterSeer }\end{array}$ & $\begin{array}{l}\text { Case-control } \\
\text { Case-event }\end{array}$ & $\mathrm{P}, \mathrm{Ag}, \mathrm{D} \& \mathrm{C}$ & $\begin{array}{l}\text { Epidemiological } \\
\text { survey }\end{array}$ & \\
\hline
\end{tabular}

* less used, P: Point, D: dichotomous variable, Ag: Aggregated data, C: continuous data

Indeed the use of frequentist approaches above describe, Bayesian approaches are also used to detect diseases clusters. A Bayesian approach might be more suited if study was conducted in order to estimate a priori probabilities of event [96]. Then, one of the biggest challenges in the Bayesian statistic is the choice of priors. Indeed, experience and a good understanding of the influence of prior distributions and convergence assessment of Markov chains are crucial in Bayesian analyses [97]. Nevertheless, Bayesian methods for the analyses are more flexible and suitable tool for inference in data sets with many missing values, or when accounting for detection probabilities [98-100]. Bayesian approaches were used to estimate prevalence of porcine cysticercosis [3] and in the test characteristics of coprology, coproantigen ELISA and a novel real-time PCR for the diagnosis of taeniasis [101].

Spatial statistic was therefore less used in identification of regions with cysticercosis in order to allow its sanitary control. Furthermore, the use of this new approach could increase the detection of most active sites for porcine cysticercosis transmission in endemic areas. Therefore, the detection of clusters become useful if authors assessed risks factors associated to diseases distribution in order to have better compre- hension of cysticercosis distribution.

\section{Contribution of tools in porcine cysticercosis control in developing countries}

Ante-mortem tongue palpation and post mortem meat inspection are public health measures used to prevent porcine cysticercosis transmission to human. These available diagnostic techniques, widely used in developing countries, are easy to use, rapid and cheap. Nevertheless ante mortem tongue palpation and postmortem meat inspection are reported to be specific and less sensitive when applied to pigs with low pigs' burdens [102,103]. Characteristics of different tests above describe were summarize in Table-1 and 2. Current available diagnostic techniques such as Ag-ELISA and EITB are found sensitive and specific. But neither of ELISA tests (B158/B60 Ag-ELISA and HP10 AgELISA) used for the diagnosis of cysticercosis is perfect $[3,104,105]$. Hence, the epidemiological data collected on T. solium cysticercosis in Africa cannot reflect the real situation of the diseases [106]. However, Ag-ELISA has the advantage to detect the presence of active infection and the level of the infective burden [107]. Nevertheless, to date the same sensitivity was not observed with the current available antigen capture 
assays and the reported specificities are not yet close to levels required for mass screening of pigs in endemic areas [107,108]. Performance of sandwich ELISA could be improved with nanobodies if good epitope could be found to bind with $T$. solium proteins [19]. Nevertheless, both Ag-ELISA and EITB is useful for epidemiological survey because require access to laboratory with proper instrument and training staff. The other immunodiagnostic techniques developed and present in this review need to be performed and require access to laboratory with proper instrument (Table-1) and well-trained staff. Hence, all those diagnostic techniques will be useful for epidemiological survey. Nevertheless, data collection in field on porcine cysticercosis will be limited by lack of laboratory instrument and fees to perform the tests. According to previous reports, pigs inspected are predominantly reared by unressources smallholder [2,109]. When considering the available resource and the social level of pig's owners and butchers, the process of testing pig sera in laboratory before purchase or before the marketing of meat is limited by fees and the delay of results [110]. Hence, processing like that could involve butchers in clandestinely. Then, to prevent transmission of porcine cysticercosis in developing countries, highest sensitive and specific diagnostic techniques, cheap, rapid and easy to use by veterinary inspector in field are needed. It is therefore important to couple any diagnostic technique with spatial statistic technique in order to identify porcine cysticercosis cluster, which allow any direct intervention or any epidemiological survey. Tools and software frequently used to detect diseases clusters are summarize in Table-2. Few applications using spatial statistic are done in cysticercosis field. Since some authors have described areas of spread of porcine cysticercosis and neurocysticercosis base on estimation [111], to date, there is lack of information on specific areas of spraying of porcine cysticercosis and neurocysticercosis. There also lack of information on spatial movement of pigs with porcine cysticercosis and on risk for urban areas to contribute of spraying the burden. Then, immunodiagnostics and spatial analysis tools are able to be developed and combined for a better control of porcine cysticercosis as well as for control of neurocysticercosis.

\section{Conclusion and recommendations}

Ante mortem tongue palpation and post mortem meat inspection are widely used in Africa for diagnosis of porcine cysticercosis. Nevertheless, both methods are limited on sensitivity. Current immunodiagnostic tests such as Ag-ELISA and EITB are found sensitive and specific. But Ag-ELISA is not perfect and both tests require access to laboratory with proper instrument and training staff.

All others methods described above were not well performed. Spatial statistic tools are available, but are less used in identification of geographical areas of distribution of porcine cysticercosis. Hence, for better control of porcine cysticercosis in zoonotic areas, it is interesting to develop diagnostic techniques with high sensitivity and specificity, handy to use, rapid and cheap. It is recommended to combine immunodiagnostic test with spatial statistical tool for better control of the tapeworm.

\section{Authors' contributions}

All authors were contributed in discussion, draft and revision of manuscript. All authors read and approved the final manuscript.

\section{Acknowledgements}

The authors are very grateful to CUD (Coopération Universitaire au Développement) for financial support and express their thanks to Prof. Pierre Dorny and Dr Sarah Gabriël of Institute of Tropical Medicine, Antwerp and Prof. Claude Saegerman of Department of Infectious and Parasitic Diseases, Research Unit of Epidemiology and Risk Analysis Applied to Veterinary Sciences (UREAR-ULg), Faculty of Veterinary Medicine, University of Liège, Liège, Belgium for their advices.

\section{Competing interests}

The authors declare that they have no competing interests.

\section{References}

1. Engels, D., Urbani, C., Belotto, A., Meslin, F., and Savioli, L. (2003) The control of human (neuro) cysticercosis: which way forward? Acta Trop. 87: 177-182.

2. Phiri, I.K., Ngowi, H., Afonso, S., Matenga, E., Boa, M., Mukaratirwa, S., Githigia, S., Saimo, M., Sikasunge, C., Maingi, N., Lubega, G.W., Kassuku, A., Michael, L., Siziya, S., Krecek, R.C., Noormahomed, E.J, Vilhena, M., Dorny, P. and Willingham III, A.L. (2003) The emergence of Taenia solium cysticercosis in Eastern and Southern Africa as a serious agricultural problem and public health risk? Acta Trop, 87: 13-23.

3. Dorny, P., Phiri, I.K., Vercruysse, Gabriel, S., Willingham III, A.L., Brandt, J., Victor, B., Speybroeck, N. and Berkvens, D. (2004) A Bayesian approach for estimating values for prevalence and diagnostic test characteristics of porcine cysticercosis, Int. J. Parasitol, 34: 569-576.

4. Miller, B., Goldberg, M.A., Heiner, D., Myers, A. and Goldberg, A. (1984) A new immunologic test for CNS cysticercosis, Neurology, 34: 695-697.

5. Tsang, V.C., Brand, J.A. and Boyer, A.E. (1989) An enzymelinked immunoelectrotransfer blot assay and glycoprotein antigens for diagnosing human cysticercosis (Taenia solium), J. Infect. Dis, 59:50-59.

6. Garcia, E. and Sotelo, J. (1991) A new complement fixation test for the diagnosis of neurocysticercosis in cerebrospinal fluid, J. Neurol, 238; 379-382.

7. Ferreira, A.P., Vaz, A.J., Nakamura, P.M., Sasaki, A.T., Ferreira, A.W. and Livramento, J.A. (1997) Hemagglutination test for the diagnosis of human neurocysticercosis: development of a stable reagent using homologous and heterologous antigens, Rev. Inst. Med. Trop. Sao Paulo, 39: 29-33.

8. Ito, A., Plancarte, A., Ma, L., Kong, Y., Flisser, A., Cho, S. Y., Liu, Y.H., Kamhawi, S., Lightowlers, M.W. and Schantz, P.M. (1998) Novel antigens for neurocysticercosis: simple method for preparation and evaluation for serodiagnosis, Am. J. Trop. Med. Hyg, 59: 291-294.

9. Rocha, S.M., Suzuki, L.A., Silva, A.D., Arruda, G.C. and Rossi, C.L. (2002) A rapid latex agglutination test for the detection of anti-cysticercus antibodies in cerebrospinal 
fluid (CSF), Rev. Inst. Med. Trop. Sao Paulo 44: 57-58.

10. Gonzalez, A.E., Cama, V., Gilman, R.H., Tsang, V.C.W., Pilcher, J.B., Chavera, A., Castro, M., Montenegro, T., Verastegui, M., Miranda, E. and Baltazar, E. (1990) Prevalence and comparison of serological assays, necropsy, and tongue examinations for the diagnosis of porcine cysticercosis in Peru, Am. J. Trop.Med. Hyg, 43: 194-199.

11. Ngowi, H.A., Kassuku, A.A., Carabin, H., Mlangwa, J.E.D., Mlozi, M.R.S., Mbilinyi, B.P. and Willingham, III A.L. (2010) Spatial Clustering of Porcine Cysticercosis in Mbulu District, Northern Tanzania, PLoS Negl Trop Dis, 4(4): e652.

12. Herenda, D., Chambers, P.G., Ettriqui, A., Seneviratna, P. and da Silva, T.J.P. (2000) Manual on meat inspection for developing countries. Reprinted 2000. Food and Agriculture Organization of the United Nations Rome, 1994. http://www.fao.org/docrep/003/t0756e/t0756e00.htm. Consulté le 30 avril 2013.

13. OIE (2012) Manuel des tests de diagnostic et des vaccins pour les animaux terrestres 2012. Manuel terrestre de l'OIE 2008. Cysticercose. http://www.oie.int/fileadmin/ Home/fr/Health_standards/tahm/Chap\% 202.9.5._ Cysticercoses_2008.pdf. Consulté le 30 avril 2013.

14. Boa, M.E., Mahundi, E.A., Kassuku, A.A., Willingham, A.L. and Kyvsgaard, N.C. (2006) Epidemiological survey of swine cysticercosis using ante-mortem and post-mortem examination tests in the southern highlands of Tanzania, Vet. Parasitol. 139: 249-255.

15. Phiri, I.K., Dorny, P., Gabriël, S., Willingham III, A.L., Sikasunge, C., Siziya, S. and Vercruysse, J. (2006) Assessment of routine inspection methods for porcine cysticercosis in Zambian village pigs, J. Helminthol, 80: 69-72.

16. Erhart, A., Dorny, P., Nguyen Van De, Ha Viet Vien, Dang Cam Thach, Nguyen Duy Toan, Le Dinh Cong, Geerts, S., Speybroeck, N., Berkvens, D. and Brandt, J. (2002) Taenia solium cysticercosis in a village in northern Vietnam: seroprevalence study using an ELISA for detecting circulating antigen, Trans. R. Soc. Trop. Med. Hyg, $96: 270$ 272.

17. Nguekam, Zoli, A.P., Vondou, L., Pouedet, S.M.R., Assana, E., Dorny, P., Brandt, J. and Geerts, S. (2003) Kinetics of circulating antigens in pigs experimentally infected with Taenia solium eggs, Vet. Parasitol, 111: 323-332.

18. Rodriguez-Hidalgo, R., Benitez-Ortiz, W., Praet, N., Saa, L.R., Vercruysse, J., Brandt, J. and Dorny, P. (2006) Taeniasis-cysticercosis in Southern Ecuador: assessment of infection status using multiple laboratory diagnostic tools, Mem. Inst. Oswaldo Cruz, 101: 779-782.

19. Deckers, N., Saerens, D., Kanobana, K., Conrath, K., Victor, B., Wernery, U., Vercruysse, J., Muyldermans, S. and Dorny, P. (2009) Nanobodies, a promising tool for species-specific diagnosis of Taenia solium cysticercosis, Int. J. Parasitol, 39: 625-633.

20. Hamers-Casterman, C., Atarhouch, T., Muyldermans, S., Robinson, G., Hamers, C., Songa, E.B., Bendahman, N. and Hamers, R. (1993) Naturally occurring antibodies devoid of light chains, Nature, 363: 446-448.

21. Frenken, L.G.J, van der Linden, R.H.J, Hermans, P.W.J. J., Ruuls, R.C, De Geus B and Verrips, C.T. (2000) Isolation of antigen specific Llama VHH antibody fragments and their high level secretion by Saccharomyces cerevisiae, $J$ Biotechnol, 78: 11-21.

22. Lauwereys, M., Arbabi, G.M., Desmyter, A., Kinne, J., Holzer, W., De Genst, E., Wyns, L. and Muyldermans, S. (1998) Potent enzyme inhibitors derived from dromedary heavy-chain antibodies, EMBOJ, 17:3512-3520.

23. De Genst, E., Silence, K., Decanniere, K., Conrath, K., Loris, R., Kinne, J., Muyldermans, S. and Wyns, L. (2006) Molecular basis for the preferential cleft recognition by dromedary heavy-chain antibodies, Proc Natl Acad Sci US A, 103: 4586-4591.

24. De Genst, E.J., Guilliams, T., Wellens, J., O'Day, E.M.,
Waudby, C.A., Meehan, S., Dumoulin, M., Hsu, S.T., Cremades, N., Verschueren, K.H., Pardon, E., Wyns, L., Steyaert, J., Christodoulou, J. and Dobson, C.M. (2010) Structure and properties of a complex of alpha-synuclein and a single-domain camelid antibody, J. Mol. Biol, 402: 326343.

25. de Marco, A. (2011) Biotechnological applications of recombinant single-domain antibody fragments, Microb Cell Fact, 10:44.

26. Esquivel-Velázquez, M., Larralde, C., Morales, J. and OstoaSaloma, P. (2011) Protein and Antigen Diversity in the Vesicular Fluid of Taenia Solium Cysticerci Dissected from Naturally Infected Pigs, Int. J. Biol. Sci, 7(9):1287-1297.

27. Bobes, R.J., Fragoso, G., Reyes-Montes, M. R., DuarteEscalante, E., Vega, R., de Aluja, A.S., Zuniga, G., Morales, J., Larralde, C. and Sciutto, E. (2009) Genetic diversity of Taenia solium cysticerci from naturally infected pigs of central Mexico, Vet. Parasitol, 168: 130-135.

28. Deckers, N., Dorny, P., Kanobana, K., Vercruysse, J., Gonzalez, A.E., Ward, B. and Ndao. M. (2008) Use of ProteinChip technology for identifying biomarkers of parasitic diseases: The example of porcine cysticercosis (Taenia solium), Exp. Parasitol, 120:320-329.

29. Chen, Y.D., Zheng, S., Yu, J.K. and Hu, X. (2004) Artificial neural networks analysis of surface-enhanced laser desorption/ionization mass spectra of serum protein pattern distinguishes colorectal cancer from healthy population, Clin. Cancer Res, 10(24): 8380-8385.

30. Kumar, N., Maurya, P., Gammell, P., Dowling, P., Clynes, M. and Meleady, P. (2008) Proteomic profiling of secreted proteins from $\mathrm{CHO}$ cells using surface-enhanced laser desorption ionization time-of-flight mass spectrometry, Biotechnol. Prog, 24(1): 273-278.

31. Melle, C., Ernst, G., Schimmel, B., Bleul, A., Mothes, H., Kaufmann, R., Settmacher, U. and von Eggeling, F. (2006) Different expression of calgizzarin (S100A11) in normal colonic epithelium, adenoma and colorectal carcinoma, Int. J. Oncol, 28(1): 195-200.

32. Xu, W.H., Chen, Y.D., Hu, Y., Yu, J.K., Wu, X.G., Jiang, T.J., Zheng, S. and Zhang, S.Z. (2006) Preoperatively molecular staging with CM10 ProteinChip and SELDI-TOF-MS for colorectal cancer patients, J. Zhejiang Univ.-Sci. B, 7(3): 235-240.

33. Enkelmann, A., Heinzelmann, J., von Eggeling, F., Walter, M., Berndt, A., Wunderlich, H. and Junker, K. (2011) Specific protein and miRNA patterns characterise tumourassociated fibroblasts in bladder cancer, J. Cancer Res. Clin. Oncol, 137(5):751-759.

34. Seibert, V., Ebert, M.P. and Buschmann, T. (2005) Advances in clinical cancer proteomics: SELDI-TOF-mass spectrometry and biomarker discovery, Briefings Funct Genomics Proteomics, 4: 16-26.

35. Engwegen, J.Y., Gast, M.C., Schellens, J.H. and Beijnen, J.H. (2006) Clinical proteomics: searching for better tumour markers with SELDITOF mass spectrometry, Trends Pharmacol, Sci, 27: 251-9.

36. Zhu, XD, Zhang WH, Li CL, Xu Y, Liang WJ and Tien P. (2004) New serum biomarkers for detection of HBV-induced liver cirrhosis using SELDI protein chip technology, World $J$ Gastroenterol, 10(16): 2327-9.

37. Poon, TC, Hui, AY, Chan, HL, Ang IL, Chow, SM, Wong, N and Sung, JJ. (2005) Prediction of liver fibrosis and cirrhosis in chronic hepatitis B infection by serum proteomic fingerprinting: a pilot study, Clin Chem, 51:328-35.

38. Karatayl, S.C., Alagöz, S.G., Mizrak, D., Sayki, M., Özkan, M., Savafi, B., Erden, E., Çinar, K., Idilman, R., Yurdaydin, C.A. and Bozdayi, M. (2012) Potential proteomic biomarkers in assessing liver fibrosis using SELDI-TOF MS. Turk J Gastroenterol. 23 (1): 46-53.

39. Göbel, T., Vorderwülbecke, S., Hauck, K., Fey, H., Häussinger, D. and Erhardt, A. (2006) New multi protein patterns differentiate liver fibrosis stages and hepatocellular 
carcinoma in chronic hepatitis $\mathrm{C}$ serum samples, World $J$ Gastroenterol, 12: 7604-12.

40. Morra, R., Munteanu, M., Bedossa, P., Dargere, D., Janneau, J.L., Paradis, V., Ratziu, V., Charlotte, F., Thibault, V., Imbert-Bismut, F. and Poynard, T. (2007) Diagnostic value of serum protein profiling by SELDI-TOF ProteinChip compared with a biochemical marker, FibroTest, for the diagnosis of advanced fibrosis in patients with chronic hepatitis C,Aliment. Pharm. Ther, 26: 847-58.

41. Diamandis EP. (2004) Analysis of serum proteomic patterns for early cancer diagnosis: drawing attention to potential problems, J Natl Cancer Inst, 96:353-6.

42. Hu, J., Coombes, K.R., Morris, J.S. and Baggerly, K.A (2005) The importance of experimental design in proteomic mass spectrometry experiments: some cautionary tales, Brief. Funct. Genomic. Proteomic, 3: 322-331.

43. Coombes, K.R., Morris, J.S., Hu, J., Edmonson, S.R. and Baggerly, K.A. (2005) Serum proteomics profiling-a young technology begins to mature, Nat. Biotechnol, 23: 291-292.

44. Dijkstra, M., Vonk, R. J. and Jansen, R. C (2007) SELDITOF mass spectra: A view on sources of variation, $J$. Chromatogr. B, 847: 12-23.

45. Issaq, H.J., Conrads, T.P., Prieto, D.A., Tirumalai, R. and Veenstra, T.D. (2003) SELDI-TOF MS for diagnostic proteomics, Anal. Chem, 75: 149A-155A.

46. Ramahefarisoa, R.M., Rakotondrazaka, M., Jambou, R. and Carod, J-F. (2010) Comparison of ELISA and PCR assays for the diagnosis of porcine cysticercosis, Vet. Parasitol, 173: 336-339.

47. Galán-Puchades, M.T., Osuna, A. and Fuentes, M.V. (2010) Letter to the Editor On the serum PCR in the diagnosis of pig cysticercosis, Vet. Parasitol, 173: 362-363.

48. Sreedevi, C., Hafeez, M.D., Anand Kumar, P., Chengalva Rayulu, V. Subramanyam K. V. and Sudhakar, K. (2012) PCR test for detecting Taenia solium cysticercosis in pig carcasses, Trop. Anim. Health. Prod, 44: 95-99.

49. Trucksess MW, Stack ME, Nesheim S, Park DL and Pohland A.E (1989) Enzyme-linked immunosorbent assay of Aflatoxins B1, B2, and G1 in corn, cottonseed, peanuts, peanut butter, and poultry feed: collaborative Study, J Assoc OffAnal Chem, 72(6): 957-962.

50. Paepens C, De Saeger S, Sibanda L, Barna-Vetro I, Leglise I, Van Hove F and Van Peteghem C. (2004) A flow-through enzyme immunoassay for the screening of fumonisins in maize, Anal Chim Acta, 523: 229-235.

51. Sreedevi, C., Hafeez, M.D., Subramanyam, K.V., Anand Kumar, P., and Chengalva Rayulu, V. (2011) Development and evaluation of flow through assay for detection of antibodies against porcine cysticercosis, Trop. Biomed, 28(1): 160-170.

52. Chung, J.Y., Eom, K.S., Yang, Y., Li, X., Feng, Z., Rim, H.J., Cho, S.Y. and Kong, Y. (2005) A seroepidemiological survey of Taenia solium cysticercosis in Nabo, Guangxi Zhuang Autonomous Region, China, Korean J.Parasitol, 43(4): 135139.

53. Lowry, O.H., Rosebrough, N.J., Farr, A.L., and Randall, R.J. (1951) Protein measurement with the Folin phenol reagent, J. Biol. Chem, 193: 265-275.

54. Amit, P., Prasad, K.N., Kumar, G.R., Shweta, T., Sanjeev, J., Kumar, P.V. and Mukesh, T. (2011) Immune response to different fractions of Taenia solium cyst fluid antigens in patients with neurocysticercosis, Exp. Parasitol, 127: 687-692.

55. Atluri, S.R.V., Singhib, P., Khandelwal, N. and Mallaa, N. (2009) Neurocysticercosis immunodiagnosis using Taenia solium cysticerci crude soluble extract, excretory secretory and lower molecular mass antigens in serum and urine samples of Indian children, Acta Trop, 110: 22-27.

56. Suzuki, L.A. and Rossi, C.L. (2011) Evaluation of two Taenia solium cysticercal antigenic preparations (vesicular fluid and a glycoprotein fraction with affinity for lentil lectin) for the immunodiagnosis of neurocysticercosis by enzyme-linked immunosorbent assay (ELISA), Arq. Neuropsiquiatr, 69(3): 470-474.

57. Zheng, M. Z., Richard, J. L. and Binder, J. (2006) A review of rapid methods for the analysis of mycotoxins, Mycopathologia, 161:261-273.

58. Moore, D.A. and Carpenter, T.E. (1999) Spatial analytical methods and geographic information systems: use in health research and epidemiology, Epidemiol Rev, 21: 143-161.

59. Paireau, J., Girond, F., Collard, J.M., Maïnassara, H.B. and Jusot, J.F. (2012) Analysing Spatio-Temporal Clustering of Meningococcal Meningitis Outbreaks in Niger Reveals Opportunities for Improved Disease Control, PLoS Negl Trop Dis, 6(3): e1577.

60. Cuzick, J. and Edwards, R. (1990) Spatial clustering for inhomogeneous populations. J. R. Stat. Soc. Ser. B, 52: 73104.

61. Besag, J. and Newell, J. (1991) The detection of clusters in rare diseases. J. R. Stat. Soc. Ser. A 154: 143-155.

62. Munch, Z., Van Lill, S.W.P., Booysen, C.N., Zietsman, H.L., Enarson, D.A. and Beyers, N. (2003) Tuberculosis transmission patterns in a high-incidence area: a spatial analysis, Int. J. Tuberc. Lung Dis, 7(3): 271-277.

63. Clements, A.C.A., Lwambo, N.J.S., Blair, L., Nyandindi, U., Kaatano, G., Kinung'hi, S., Webster, J. P., Fenwick, A. and Brooker, S. (2006) Bayesian spatial analysis and disease mapping: tools to enhance planning and implementation of a schistosomiasis control programme in Tanzania, Trop. Med. Int. Health, 11 (4): 490-503.

64. Brooker, S. and Clements A.C.A. (2009) Spatial heterogeneity of parasite co-infection: Determinants and geostatistical prediction at regional scales, Int. J. Parasitol, 39: 591-597.

65. Jonsson, M.E, Heier, B.T., Norström, M. and Hofshagen, M. (2010) Analysis of simultaneous space-time clusters of Campylobacter spp. in humans and in broiler flocks using a multiple dataset approach, Int. J. Health. Geogr, 9:48.

66. Pullan, R.L., Kabatereine, N.B., Quinnell, R.J. and Brooker, S. (2010) Spatial and Genetic Epidemiology of Hookworm in a Rural Community in Uganda, PLoS Negl Trop Dis, 4(6): e713.

67. Vazquez-Prokopec, G.M., Kitron, U., Montgomery, B., Horne, P. and Ritchie, S.A. (2010) Quantifying the Spatial Dimension of Dengue Virus Epidemic Spread within a Tropical Urban Environment, PLoS Negl Trop Dis, 4(12): e920.

68. Wardrop, N.A., Atkinson, P.M., Gething, P.W., Fèvre, E.M., Picozzi, K., Kakembo, A.S.L. and Welburn, S.C. (2010) Bayesian Geostatistical Analysis and Prediction of Rhodesian Human African Trypanosomiasis, PLoS Negl Trop Dis, 4(12): e914.

69. Magalhaes, R.J.S., Biritwum, N.K., Gyapong, J.O., Brooker, S., Zhang, Y., Blair, L., Fenwick A., and Clements, A.C.A. (2011) Mapping Helminth Co-Infection and Co-Intensity: Geostatistical Prediction in Ghana, PLoS Negl Trop Dis, 5(6): e1200.

70. Ripley, B.D. (1976) The second-order analysis of stationary point processes. J Appl Probab 13: 255-266.

71. Diggle, P.J. and Chetwynd, A.G. (1991) Second-order analysis of spatial clustering for inhomogeneous populations, Biometrics, 47:1155-63.

72. Bernstein, K.T., Curriero, F.C., Jennings, J.M., Olthoff, G., Erbelding, E.J. and Zenilman, J. (2004) Defining core gonorrhea transmission utilizing spatial data, Am. J. Epidemiol, 160: 51-58.

73. Austin, S.B., Melly, S.J., Sanchez, B.N., Patel, A., Buka, S. and Gortmaker, S.L. (2005) Clustering of fast-food restaurants around schools: a novel application of spatial statistics to the study of food environments, Am. J. Public Health, 95: 1575-81.

74. Potthoff, R.F. and Whittinghill, M. (1966) Testing for homogeneity. II. The Poisson distribution, Biometrika, 53: 183-90.

75. Kleinschmidt, I., Sharp, B.L., Clarke, G.P., Curtis, B. and 
Fraser, C. (2001) Use of generalized linear mixed models in the spatial analysis of small-area malaria incidence rates in Kwazulu Natal, South Africa, Am. J. Epidemiol, 153: 1213-21.

76. Michelozzi. P., Capon, A., Kirchmayer, U., Forastiere, F., Biggeri, A., Barca, A. and Perucci, C.A. (2002) Adult and childhood leukemia near a high-power radio station in Rome, Italy, Am. J. Epidemiol, 155:1096-103.

77. Abdullah, N.A., Pearce, M.S., Parker, L., Wilkinson, J.R. and McNally, R.J. (2007) Evidence of an environmental contribution to the aetiology of cryptorchidism and hypospadias? Eur. J. Epidemiol, 22: 615-20.

78. Schmiedel, S., Blettner, M., Kaatsch, P. and Schuz, J. (2010) Spatial clustering and space-time clusters of leukemia among children in Germany, 1987-2007, Eur. J. Epidemiol, 25: 627-33.

79. Moran, P.A. (1950) Notes on continuous stochastic phenomena, Biometrika, 37: 17-23.

80. Kulldorff, M. (2001) Prospective time periodic geographical disease surveillance using a scan statistic, J. R. Stat. Soc. Ser. Stat. Soc, 164: 61-72.

81. Tango, T. (2000) A test for spatial disease clustering adjusted for multiple testing, Stat. Med, 19: 191-204.

82. Song. C. and Kulldorff, M. (2003) Power evaluation of disease clustering tests, Int. J. Health Geogr, 2:9.

83. Anselin, L. (1995) Local Indicators of Spatial Association-LISA, Geogr. Anal, 27: 93-115.

84. Greene, S.K., Ionides, E.L. and Wilson, M.L. (2006) Patterns of influenza-associated mortality among US elderly by geographic region and virus subtype, 1968-1998, Am. J. Epidemiol, 163: 316-26.

85. Oyana, T.J., Rogerson, P. and Lwebuga-Mukasa, J.S. (2004) Geographic clustering of adult asthma hospitalization and residential exposure to pollution at a United States-Canada border crossing, Am. J. Public Health, 94: 1250-57.

86. Kulldorff, M. (1997) A spatial scan statistic. Part A Theory Methods. Commun. Stat. 26: 1481-96.

87. Kulldorff, M., Huang, L., Pickle, L. and Duczmal, L. (2006a) An elliptic spatial scan statistic, Stat.Med, 25:3929-43.

88. Kulldorff, M., Song, C., Gregorio, D., Samociuk, H. and DeChello. L. (2006b) Review-Cancer map patterns: Are they random or not? Am. J. Prev. Med, 30: S37-49.

89. Diggle, P.J. (1990) A point process modeling approach to raised incidence of a rare phenomenon in the vicinity of a prespecified point, J. R. Stat. Soc. Ser. Stat. Soc, 153:349-62.

90. Stone, R.A. (1988) Investigations of excess environmental risks around putative sources-statistical problems and a proposed test, Stat. Med, 7: 649-60.

91. Morales, J., Martinez, J.J., Rosetti, M., Fleury, A., Maza, V., Hernandez, M., Villalobos, N., Fragoso, G., de Aluja, A.S., Larralde, C and Sciutto, E. (2008) Spatial Distribution of Taenia solium Porcine Cysticercosis within a Rural Area of Mexico, PLoS Negl Trop Dis, 2(9), e284.

92. Lescano, A. G., Garcia, H, H., Gilman, R, H., Guezala, M. C., Tsang, V. C. W., Gavidia, C. M., Rodriguez, S., Moulton, L, H., Green, J. A., Gonzalez, A. E., and the Cysticercosis Working Group In Peru. (2007) Swine cysticercosis hotspots surrounding taenia solium tapeworm carriers, Am. J. Trop. Med. Hyg, 76(2): 376-383.

93. Mwape, K. E., Phiri, I. K., Praet, N., Muma, J. B., Zulu, G., Van den Bossche, P., de Deken, R., Speybroeck, N., Dorny, P . and Gabriël, S. (2012) Taenia solium Infections in a Rural Area of Eastern Zambia-A Community Based Study, PLoS Negl Trop Dis, 6(3), e1594.

94. Venkata Raghava, M., Prabhakaran, V., Jayaraman, T., Muliyil, J., Oommen, A., Dorny, P., Vercruysse, J. and Rajshekhar, V. (2010) Detecting spatial clusters of Taenia solium infections in a rural block in South India. Trans. $R$. Soc. Trop. Med. Hyg. 104: 601-612.

95. Thomas, L. F., de Glanville, W. A., Cook, E. A., and Fèvre, E. M. (2013) The spatial ecology of free-ranging domestic pigs (Sus scrofa) in western Kenya, BMC Vet. Res., 9: 46.
96. Berger, Z. (2010) Bayesian and frequentist models: legitimate choices for different purposes of clinical research, J Eval Clin Pract, 16: 1045-1047.

97. Brooks, S.P. (2003) Bayesian computation: a statistical revolution, Phil. Trans. R. Soc. Lond., 361:2681-2697.

98. Gelfand A. E., Schmidt, A. M., Wu, S., Silander, J. A., Latimer, Jr, and A., Rebelo A.G. (2005) Modelling species diversity through species level hierarchical modeling, Appl. Stat, 54: 1-20.

99. Latimer, A. M., Wu, S., Gelfand, A. E. and Silander, J. A. Jr. (2006) Building statistical models to analyze species distributions, Ecol. Appl, 16:33-50.

100. Kühn, I. Bierman, S.M., Durka, W. and Klotz, S. (2006) Relating geographical variation in pollination types to environmental and spatial factors using novel statistical methods, New Phyto, 172(1): 127-139.

101. Praet, N., Verweij, J. J., Mwape, K. E., Phiri, I. K., Muma, J. B., Zulu, G., van Lieshout, L., Rodriguez-Hidalgo, R., Benitez-Ortiz, W., Dorny, P. and Gabriël, S. (2013) Bayesian modelling to estimate the test characteristics of coprology, coproantigen ELISA and a novel real-time PCR for the diagnosis of taeniasis, Trop. Med. Int. Health, 18 (5): 608-614.

102. Sciutto, E., Martínez, J.J., Villalobos, N.M., Hernández, M., Jose', M.V., Beltrán, C., Rodarte, F., Flores, I., Bobadilla, J.R., Fragoso, G., Parkhouse, M.E., Harrison, L.J.S. and De Aluja, A.S. (1998) Limitations of current diagnostic procedures for the diagnosis of Taenia solium cysticercosis in rural pigs. Vet. Parasitol. 79: 299-313.

103. Boa, M.E., Kassuku, A.A., Willingham III, A.L., Keyyu, J.D., Phiri, I.K. and Nansen, P. (2002) Distribution and density of cysticerci of Taenia solium by muscle groups and organs in naturally infected local finished pigs in Tanzania, Vet. Parasitol, 106:155-164.

104. Assana, E., Kanobana, K., Tume, C., Zoli, P.A., Nguekam, Geerts, S., Berkvens, D. and Dorny, P. (2007) Isolation of a 14KDa antigen from Taenia solium cyst fluid by HPLC and its evaluation in enzyme linked immunosorbent assay for diagnosis of porcine cysticercosis, Res. Vet. Sci, 82:370-376.

105. Krecek, R.C., Michael, L.M., Schantz, P.M., Ntanjana, L., Smith, M.F., Dorny, P., Harrison, L.J.S., Grimm, F., Praet, N. and WillinghamIII, A.L. (2008) Prevalence of Taenia solium cysticercosis in swine from a communitybased study in 21 villages of the Eastern Cape Province, South Africa, Vet. Parasitol, 154:38-47.

106. Assana, E., Lightowlers, M.W., Zoli, A.P. and S. Geerts (2013) Taenia solium taeniosis/cysticercosis in Africa: Risk factors, epidemiology and prospects for control using vaccination. Vet. Parasitol.195:14-23.

107. Rodriguez, S., Wilkins, P. and Dorny, P. (2012) Immunological and molecular diagnosis of cysticercosis, Pathog Global Health, 106: 5.

108. Gilman, R. H., Gonzalez, A. E., Llanos-Zavalaga, F., Tsang, V. C. W., Garcia, H. H., and The Cysticercosis Working Group in Peru. (2012) Prevention and control of Taenia solium taeniasis/cysticercosis in Peru, Pathog Global Health, 106: 5.

109. Kagira, J.M., Maingi, N., Kanyari, P.W.N, Githigia, S.M., Ng'ang'a, J.C. and Gachohi, J.M. (2010) Seroprevalence of Cysticercus cellulosae and associated risk factors in freerange pigs in Kenya, J Helminthol, $84: 398-403$.

110. Gweba, M., Faleke, O.O., Junaidu, A. U., Fabiyi, J. P., and Fajinmi, A. O. (2010) Some risk factors for Taenia. solium cysticercosis in semi-intensively raised pigs in Zuru, Nigeria, Vet Italiana, 46 (1): 57-67.

111. Schantz, P.M., Cruz, M., Sarti, E. and Pawlowski, Z. (1993) Potential eradicability of taeniasis and cysticercosis, Bull Pan Am Health Organ, 27: 397-403.

112. Goussanou, J. S. E., Kpodekon, M. T., Saegerman, C., Azagoun, E., Youssao, A. K. I., Farougou, S., Praet, N., Gabriël, S., Dorny, P. and Korsak, N. (2013) Spatial distribution and risks factors of porcine cysticercosis in 
southern Benin based meat inspection records. Int Res $J$ Microbiol. 4(8): 188-196.

113. Gay, E. (2006) Détection d'agrégats spatiaux dans le cas d'une variable continue: application à un indicateur de l'infection mammaire chez les bovins. Thèse de doctorat. Université Blaise Pascal Clermont II \&Université D'auvergne Clermont I.

114. Auchincloss, A. H., Gebreab, S.Y., Mair, C., and Diez Roux, A.V. (2012) A Review of Spatial Methods in Epidemiology, 2000-2010, Annu. Rev. Public Health 2012, 33: 107-22.

115. Gaudart, J., Giorgi, R., Poudiougou, B., Touré, O., Ranque, S., Doumbo, O. and Demongeot, J. (2007) Détection de clusters spatiaux sans point source prédéfini : utilisation de cinq méthodes et comparaison de leurs résultats, Rev Epidemiol Santé, 55 : 297-306.

116. Fritz, C. E., Schuurman, N., Robertson, C. and Lear, S. (2013) A scoping review of spatial cluster analysis techniques for point-event data, Geospatial Health, 7(2): 183-198.

117. Wakefield, J.C., Kelsall, J.E. and Morris, S.E. (2000) Clustering, cluster detection, and spatial variation in risk. In: Elliott, P., Wakefield, J.C., Best, N.G., Briggs, D.J., (dir.). Spatial epidemiology: methods and applications. Oxford: Oxford University Press. p. 128-52.

$* * * * * * * *$ 